\title{
Modelowanie i migracja zero-offset stref uskokowych w ośrodku o azymutalnej anizotropii HTI (horizontal transverse isotropy)
}

\begin{abstract}
W artykule zaprezentowano studium modelowania sekcji czasowych zero-offset oraz odwzorowań migracyjnych dla uskoków warstw anizotropowych HTI (Horizontal Transverse Isotropy). Badano uskoki pionowe i nachylonych warstw w aspekcie wpływu kąta azymutalnego na charakter zero-offsetowej sekcji. Stwierdzono, że w tym przypadku pole falowe zero-offset jest niezależne od kąta azymutalnego, ponieważ kształtują je pionowe przebiegi fal. Odwzorowanie uskoków wykonywano, stosując migrację MG(F-K) w dziedzinie liczb falowych (K) i częstotliwości (F). Uzyskano rozdziel-

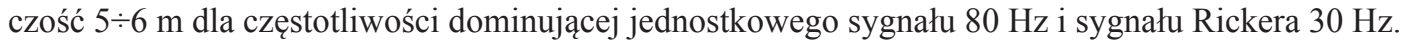

Słowa kluczowe: poziomo-poprzeczna anizotropia (HTI), modelowanie zero-offset sekcji czasowych, migracja zero-offset sekcji czasowych, anizotropia azymutalna.

\section{Modeling and migration of zero-offset thrust zones in horizontal transverse isotropy (HTI) media}

In this paper, we present the study of zero-offset section modeling and migration for the vertical and inclined thrust of anisotropic HTI layers. We investigated the influence of the azimuthal angle on zero-offset sections. In the case of vertical and moderate inclined thrusts, as has been tested and found, the zero-offset sections are independent of the azimuthal angle because the vertical rays of waves, shape the zero-offset wavefield. The imaging of thrusts was carried out by using MG(F-K) migration in wave number - frequency domain. For a dominant frequency of $80 \mathrm{~Hz}$ spike signal and $30 \mathrm{~Hz}$ Ricker's signal, a resolution of $5 \div 6 \mathrm{~m}$ was obtained.

Key words: horizontal transverse isotropy (HTI), modeling of zero-offset time sections, migration of zero-offset time sections, azimuthal anisotropy.

\section{Wstęp}

Niniejszy artykuł stanowi kontynuację problematyki modelowania i odwzorowania struktur uskokowych w ośrodkach anizotropowych zasygnalizowanej w referacie autorów na X Międzynarodowej Konferencji Geopetrol 2016 [6]. Zaprezentowano w nim podstawy teoretyczne modelowania pola falowego zero-offset i odwzorowania struktur uskokowych w ośrodkach o horyzontalnej poprzecznej izotropii (HTI) na przykładzie pionowych i nachylonych uskoków kształtowanych przez pole falowe o częstotliwości w zakresie $15 \div 80 \mathrm{~Hz}$.

\section{Modelowanie}

Punktem wyjścia w rozważaniach teoretycznych odnośnie do propagacji fal jest równanie dyspersyjne wyprowadzone z pełnego systemu równań sprężystych. Rozwiązanie tego równania, tj. określenie częstości własnej $\omega_{a}$ jako funkcji liczb falowych, posłużyło do sformułowania związku:

$$
\frac{\omega_{a}^{2}}{V_{\mathrm{p}}^{2}}=k_{a}^{2}\left(k_{x}, k_{y}, k_{z}, \theta, \Psi, \varepsilon, \delta\right)
$$

gdzie $k_{a}^{2}\left(k_{x}, k_{y}, k_{z}, \theta, \Psi, \varepsilon, \delta\right)$ jest funkcją liczb falowych $k_{x}$, $k_{y}, k_{z}$ oraz parametrów anizotropii Thomsena [8] $\varepsilon$ i $\delta$ oraz 
kąta upadu $\theta$ i azymutalnego $\Psi, V_{p}$ jest prędkością izotropową fal podłużnych.

Następstwem uniwersalnej formuly (1), obowiązującej dla wszystkich typów poprzecznej izotropii TI (transverse isotropy) $[3,4,5]$, jest jednostronne równanie falowe:

$$
\frac{\partial P\left(k_{x}, k_{z}, t\right)}{\partial t}= \pm i V_{p} k_{a} P\left(k_{x}, k_{z}, t\right)
$$

gdzie $P\left(k_{x}, k_{z}, t\right)$ oznacza pole falowe w dwuwymiarowym przypadku (2D) we współrzędnych liczb falowych, $t$-czas, $i=\sqrt{-1}$.

Równanie (2) w dwuwymiarowym przypadku można przedstawić $\mathrm{w}$ postaci:

$$
P(x, z, t)=\sum_{k x} \sum_{k y} P\left(k_{x}, k_{z}, t=0\right) \exp \left[i\left(k_{x} x+k_{z} z \pm \omega_{a} t\right)\right]
$$

Znak \pm w równaniach (2) i (3) decyduje o kierunku propagacji fal. W układzie współrzędnych prostokątnych o osi $Z$ skierowanej „w dół” znak „," oznacza propagację w kierunku poziomu rejestracji $z=0$.

W ośrodku niejednorodnym równanie (2) należy zastąpić pseudospektralną formą:

$$
\frac{\partial P(x, z, t)}{\partial t}=i V_{p}(x, z) F^{-1}\left\{k_{a} F[P(x, z, t)]\right\}
$$

gdzie $F\left(x \rightarrow k_{x}, z \rightarrow k_{z}\right)$ i $F^{-1}\left(k_{x} \rightarrow x, k_{z} \rightarrow z\right)$ oznaczają dwuwymiarowe operatory Fouriera $\mathrm{z}$ domeny $(x, z)$ do dziedziny $\left(k_{x}, k_{z}\right)-\mathrm{i}$ odwrotnie.

Relację (4) stosuje się zarówno w ośrodkach anizotropowych, jak i izotropowych. W tym ostatnim przypadku funkcja $k_{a} \rightarrow K=\left(k_{x}^{2}+k_{z}^{2}\right)^{1 / 2}$ przekształca się w wektor falowy $K$.

Numeryczne rozwiązanie propagacji falowej w czasie $t$ można uzyskać, stosując szereg Taylora ograniczony do trzech wyrazów:

$$
P(x, z, t)=\sum_{l=0}^{3} \frac{\partial^{l} P(x, z, 0)}{\partial t^{l}} \frac{\Delta t^{l}}{l !}
$$

co zabezpiecza stabilność procesu dla izotropowego przypadku [1].

Warunkiem początkowym jednostronnego równania (2) jest relacja (3) dla $t=0$, tj. $P(x, z, t=0)$. Modelowanie sekcji czasowej zero-offset wykonywano metodą jednocześnie wzbudzonych granic refleksyjnych [7].

\section{Eksperymenty numeryczne}

Przedmiotem modelowania sekcji czasowych zerooffset i odwzorowań migracyjnych są modele pionowych i nachylonych uskoków HTI zanurzonych w niejednorodnym ośrodku izotropowym. Sekwencja modelowania pionowych uskoków obejmuje model geometryczno-prędkościowy (rysunek 1) o zrzucie $300 \mathrm{~m}$ i zmiennej miąższości warstwy.

Sekcja czasowa zero-offset dla uskoku o zrzucie $300 \mathrm{~m}$ i miąższości warstwy równej $300 \mathrm{~m}$ oraz kącie azymutalnym $\Psi=0^{\circ}$ uzyskana z użyciem sygnału jednostkowego o częstotliwości dominującej $80 \mathrm{~Hz}$ (rysunek 2) nie odróżnia się od pola falowego otrzymanego dla kąta azymutalnego $\Psi=90^{\circ}$ (rysunek 3). Również odwzorowania głębokościowe ośrodka uzyskane z zastosowaniem migracji MG(F-K) w dziedzinie liczb falowych (K) i częstotliwości (F) [2, 3] są nierozróżnialne (rysunki 4 i 5). Obserwacja sekcji czasowych zero-offset dla stosunkowo znacznego zrzutu $300 \mathrm{~m}$ w ośrodku HTI wskazuje, że dla pionowego uskoku pole falowe kształtowane jest przez pionową propagację fal o prędkości $V_{P}(1+2 \varepsilon)^{1 / 2}$, natomiast prędkość pozioma nie ma wpływu na charakter zarejestrowanego pola falowego. W dalszej sekwencji eksperymentów zrezygnowano więc ze śledzenia pola falowego w zależności od kąta azymutalnego, przyjmując wartość stałą równą $\Psi=45^{\circ}$.
Następny cykl eksperymentów dotyczył uskoku warstwy o miąższości $30 \mathrm{~m}$ dla różnych wartości zrzutu uskoku zanurzonego w niejednorodnym ośrodku izotropowym zaprezentowanym na rysunku 1 . Z szeregu eksperymentów przedstawiono $\mathrm{w}$ artykule te najbardziej interesujące: na rysunkach 6 i 7 dla zrzutu równego $10 \mathrm{~m}$ oraz na rysunkach 8 i 9 dla zrzutu $6 \mathrm{~m}$. Z porównań modeli geometrycznych uskoków o zrzucie $10 \mathrm{~m}$ (rysunek 10) i $6 \mathrm{~m}$ (rysunek 11) z migracjami na rysunku 7 i 9 wynika, że odwzorowania migracyjne są zgodne z założeniami.

We wszystkich eksperymentach modelowań sekcje zerooffset zawierają nachyloną granicę refleksyjną w postaci fałszywego uskoku. Tego rodzaju deformacje pola falowego upodobniające się do wyżej leżącego rzeczywistego uskoku spowodowane są nieciągłościami niejednorodnego ośrodka, a więc skokowymi zmianami prędkości $V_{N M O}$. Ten sam eksperyment został wykonany w zakresie niewielkich zrzutów: $10 \mathrm{~m}$ (rysunki 12 i 13) i 6 m (rysunki 14 i 15) przy użyciu sygnału Rickera $30 \mathrm{~Hz}$ i wykazał możliwość uzyskania prawidłowego odwzorowania nawet dla stosunkowo małego zrzutu $6 \mathrm{~m}$. Następna sekwencja eksperymentów wykonanych przy użyciu sygnału $15 \mathrm{~Hz}$ skutkuje stopniowym zanikiem oznak uskoku na sekcjach zero-offset. Na sekcji dla miąższości warstwy równej $30 \mathrm{~m}$ i zrzutu $10 \mathrm{~m}$ uskok nie jest widoczny (rysunek 16). 


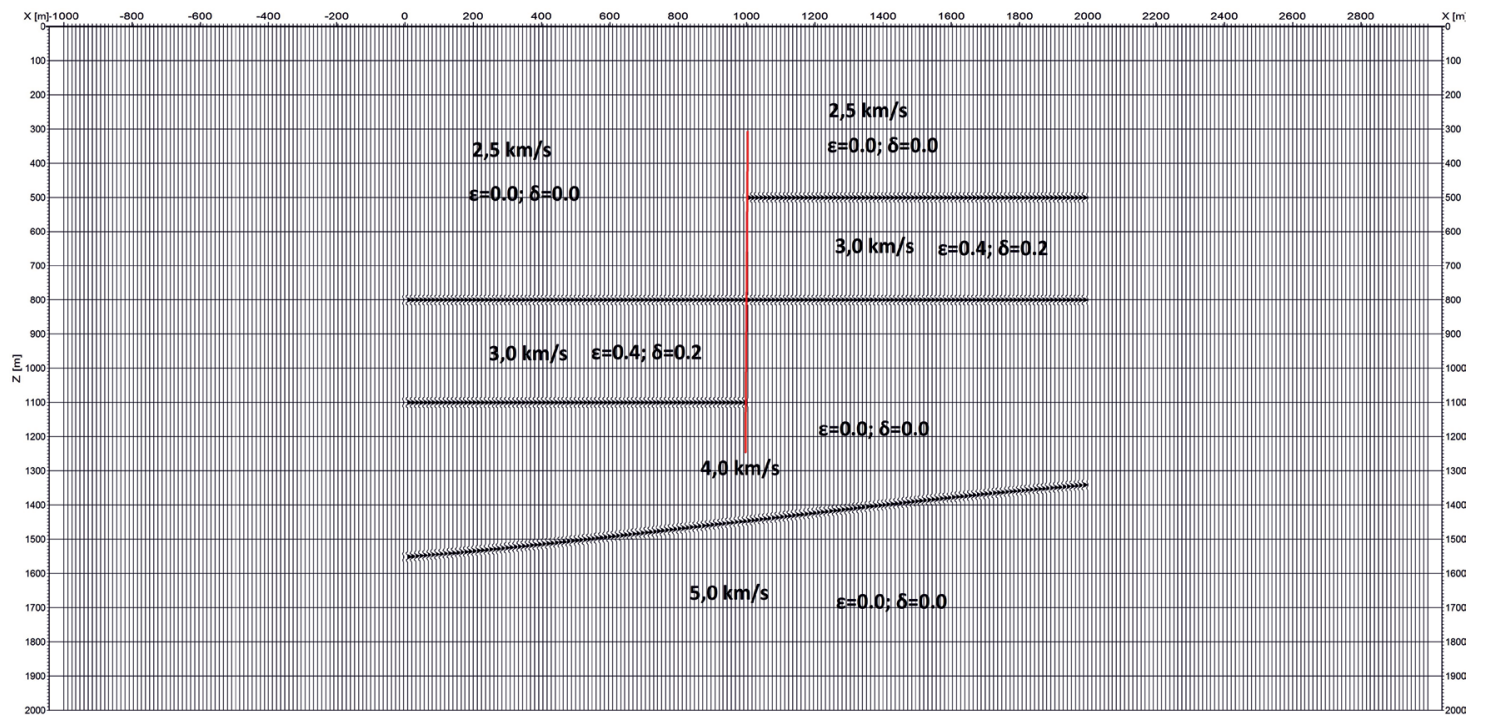

Rys. 1. Model geometryczno-prędkościowy strefy uskokowej

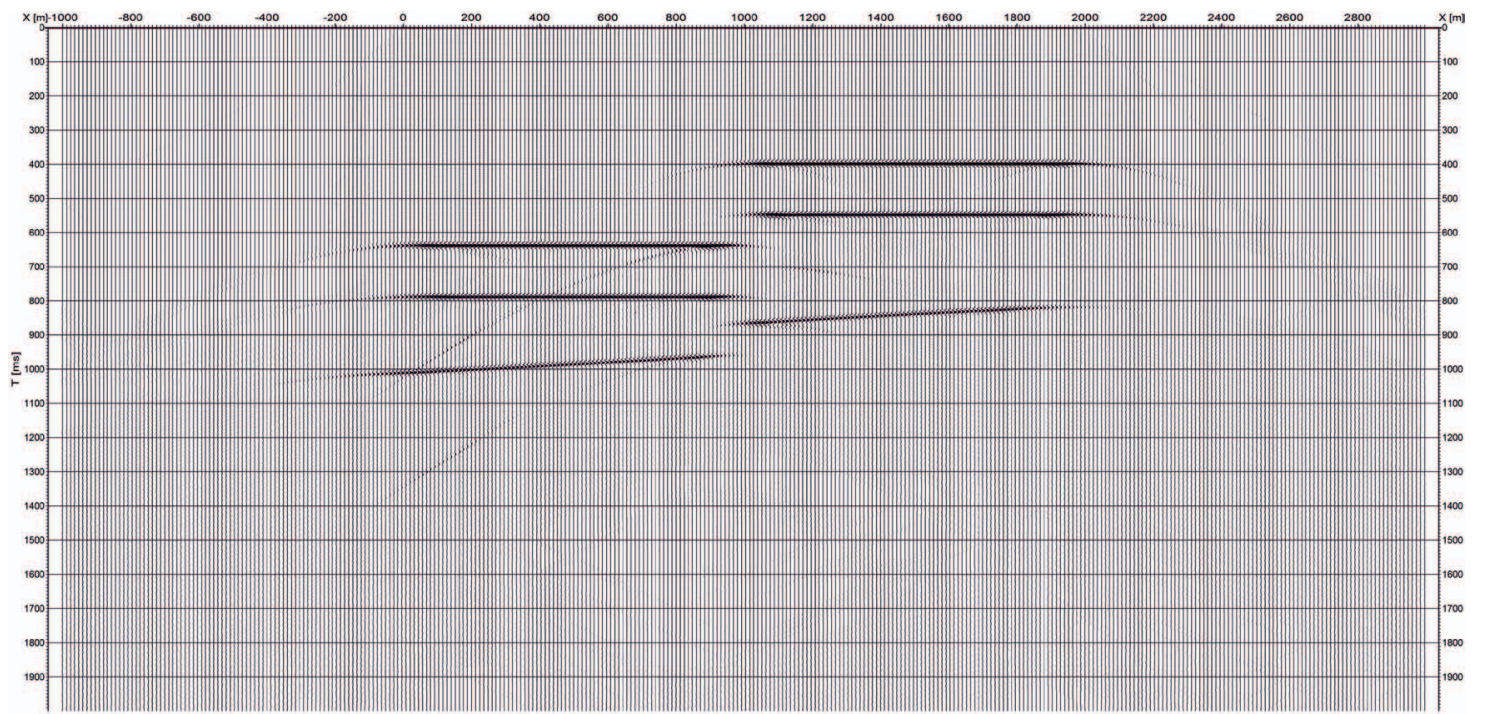

Rys. 2. Sekcja czasowa zero-offset dla uskoku o zrzucie $300 \mathrm{~m}$ i miąższości warstwy równej 300 m; parametry anizotropii: $\varepsilon=0,4 ; \delta=0,2 ;$ kąt azymutalny $\Psi=0^{\circ}$. Sygnał jednostkowy o częstotliwości dominującej $80 \mathrm{~Hz}$

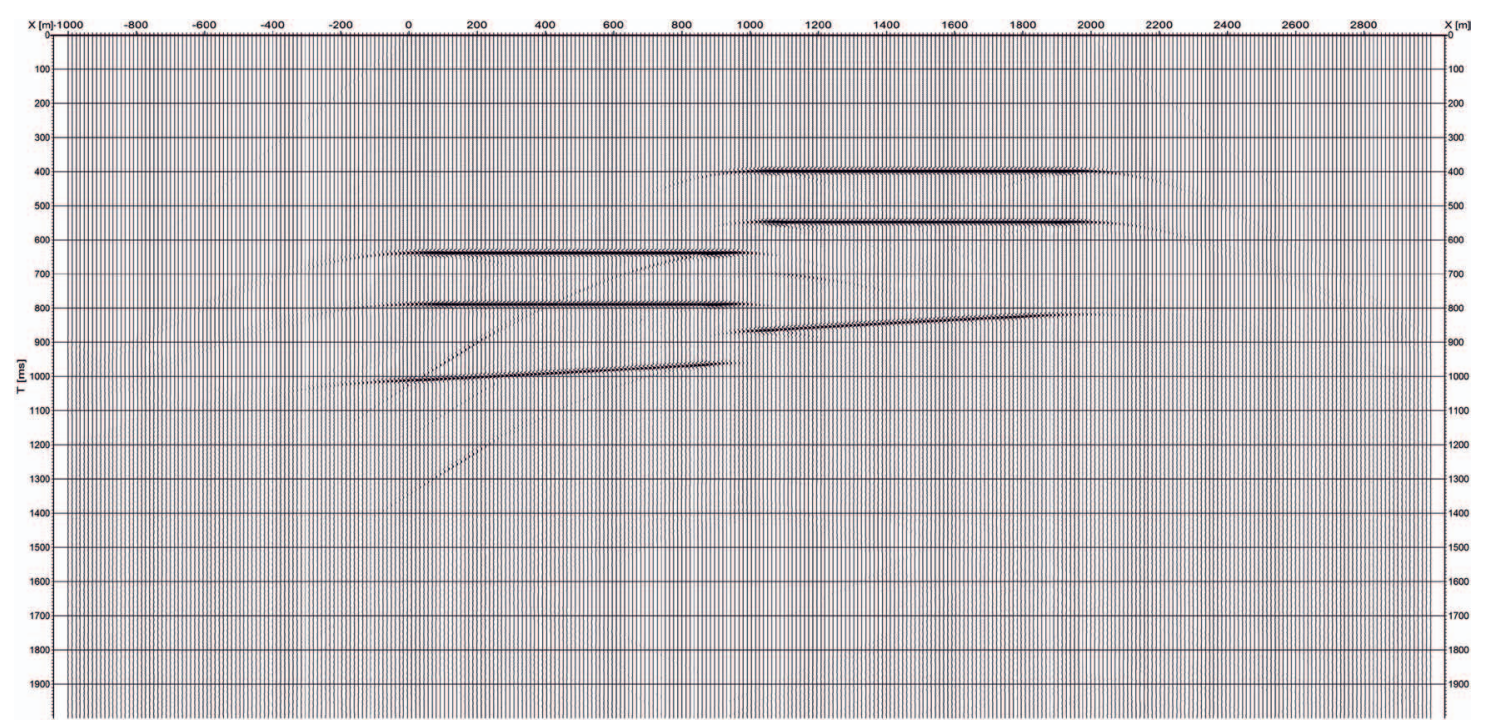

Rys. 3. Sekcja czasowa zero-offset dla uskoku o zrzucie $300 \mathrm{~m}$ i miąższości warstwy równej 300 m; parametry anizotropii: $\varepsilon=0,4 ; \delta=0,2 ;$ kąt azymutalny $\Psi=90^{\circ}$. Sygnał jednostkowy o częstotliwości dominującej $80 \mathrm{~Hz}$ 


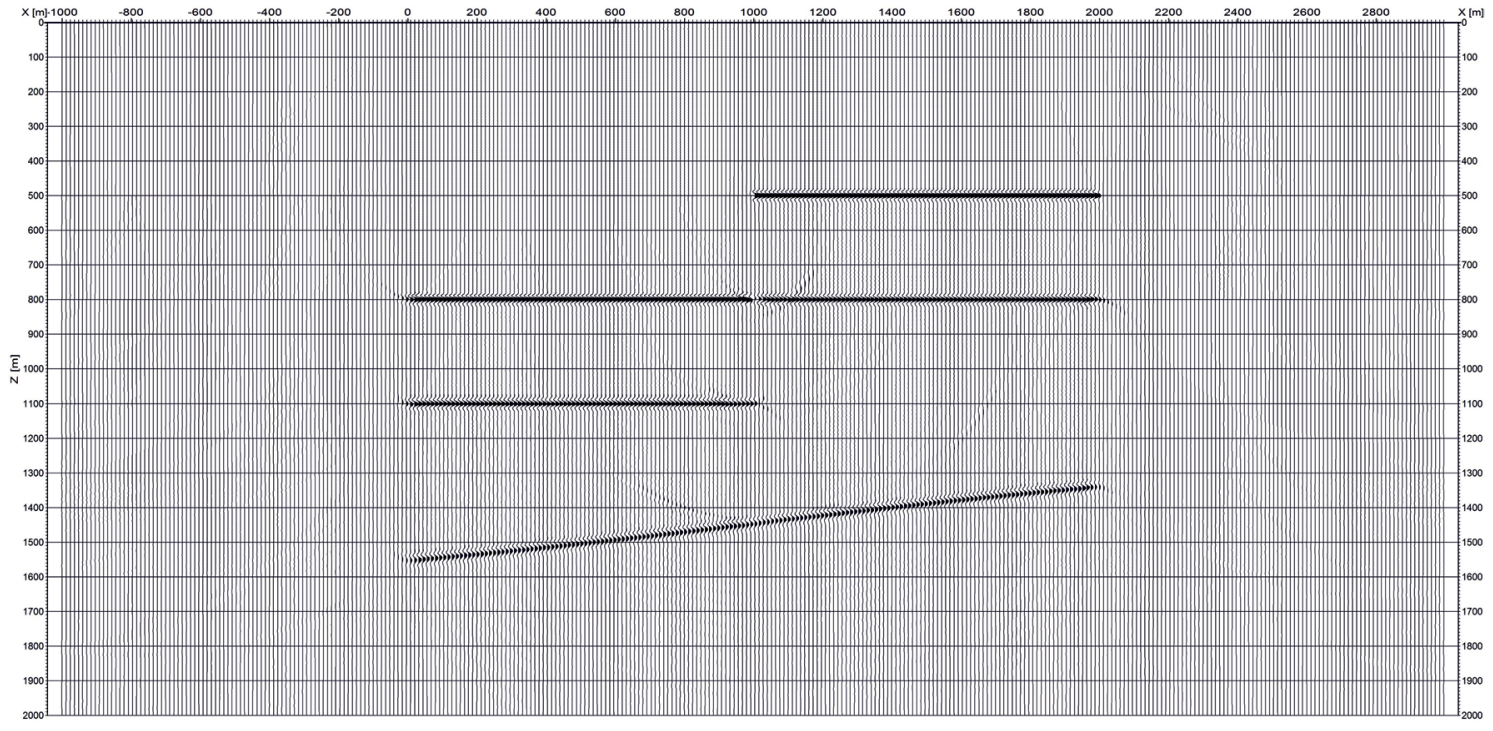

Rys. 4. Migracja zero-offset dla uskoku o zrzucie $300 \mathrm{~m}$ i miąższości warstwy równej $300 \mathrm{~m}$; parametry anizotropii: $\varepsilon=0,4 ; \delta=0,2 ;$ kąt azymutalny $\Psi=0^{\circ}$. Sygnał jednostkowy o częstotliwości dominującej $80 \mathrm{~Hz}$

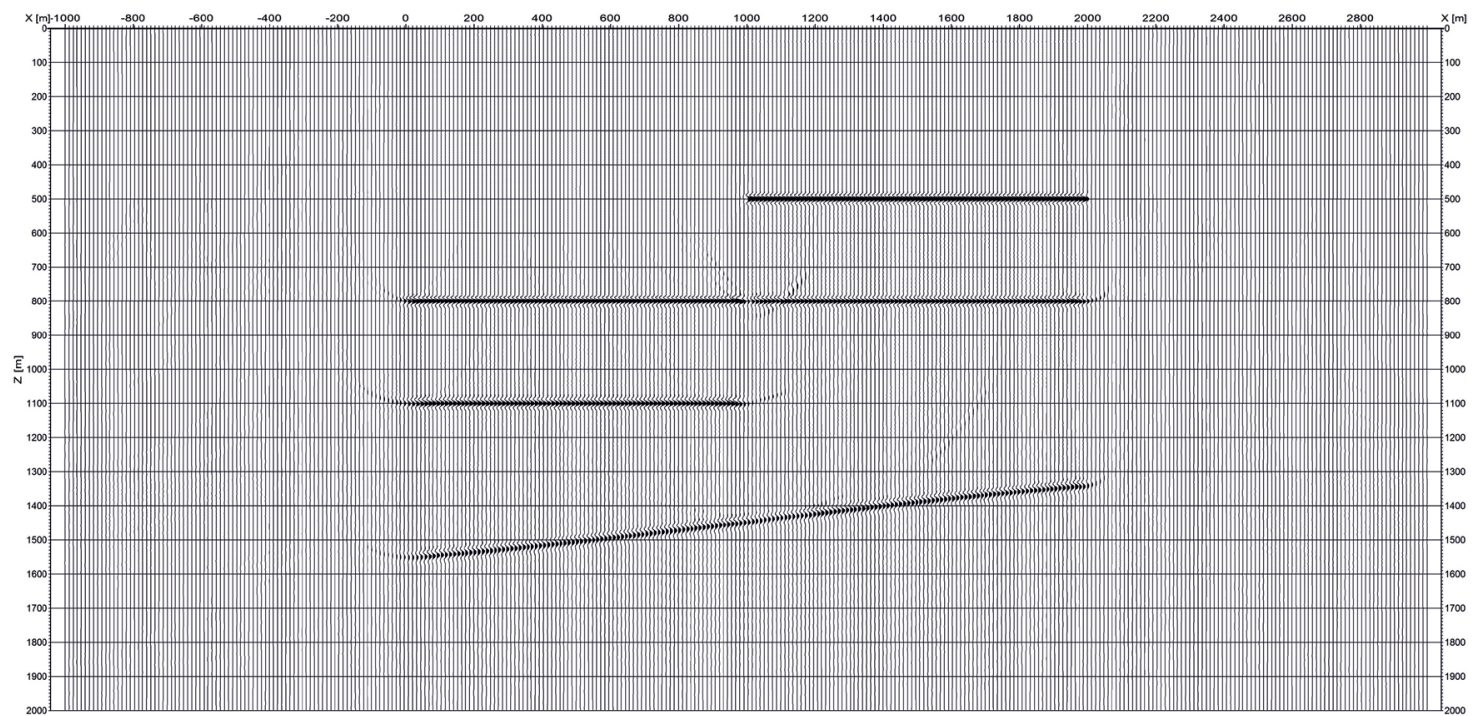

Rys. 5. Migracja zero-offset dla uskoku o zrzucie $300 \mathrm{~m}$ i miąższości warstwy równej $300 \mathrm{~m}$; parametry anizotropii: $\varepsilon=0,4 ; \delta=0,2 ;$ kąt azymutalny $\Psi=90^{\circ}$. Sygnał jednostkowy o częstotliwości dominującej $80 \mathrm{~Hz}$

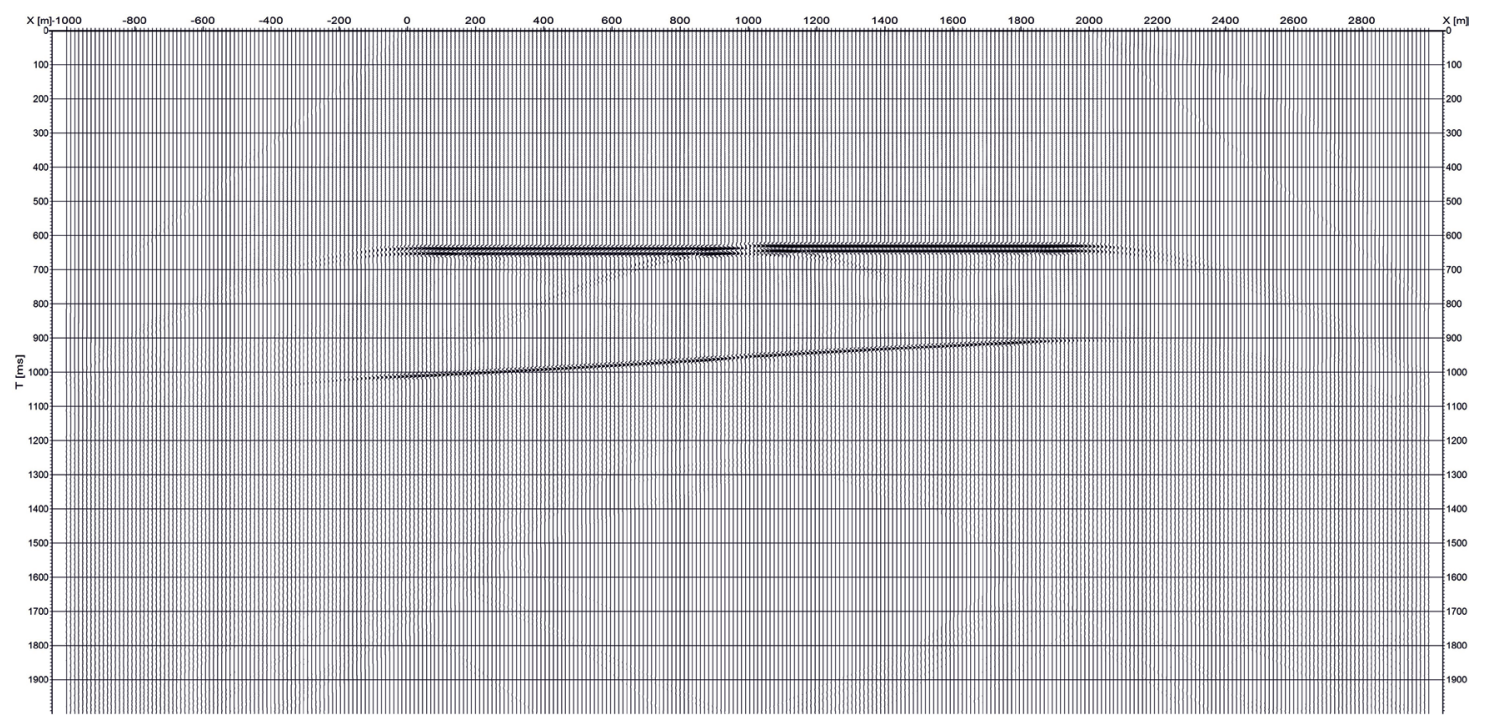

Rys. 6. Sekcja czasowa zero-offset dla uskoku o zrzucie $10 \mathrm{~m}$ i miąższości warstwy równej $30 \mathrm{~m}$; parametry anizotropii: $\varepsilon=0,4 ; \delta=0,2 ;$ kąt azymutalny $\Psi=45^{\circ}$. Sygnał jednostkowy o częstotliwości dominującej $80 \mathrm{~Hz}$ 


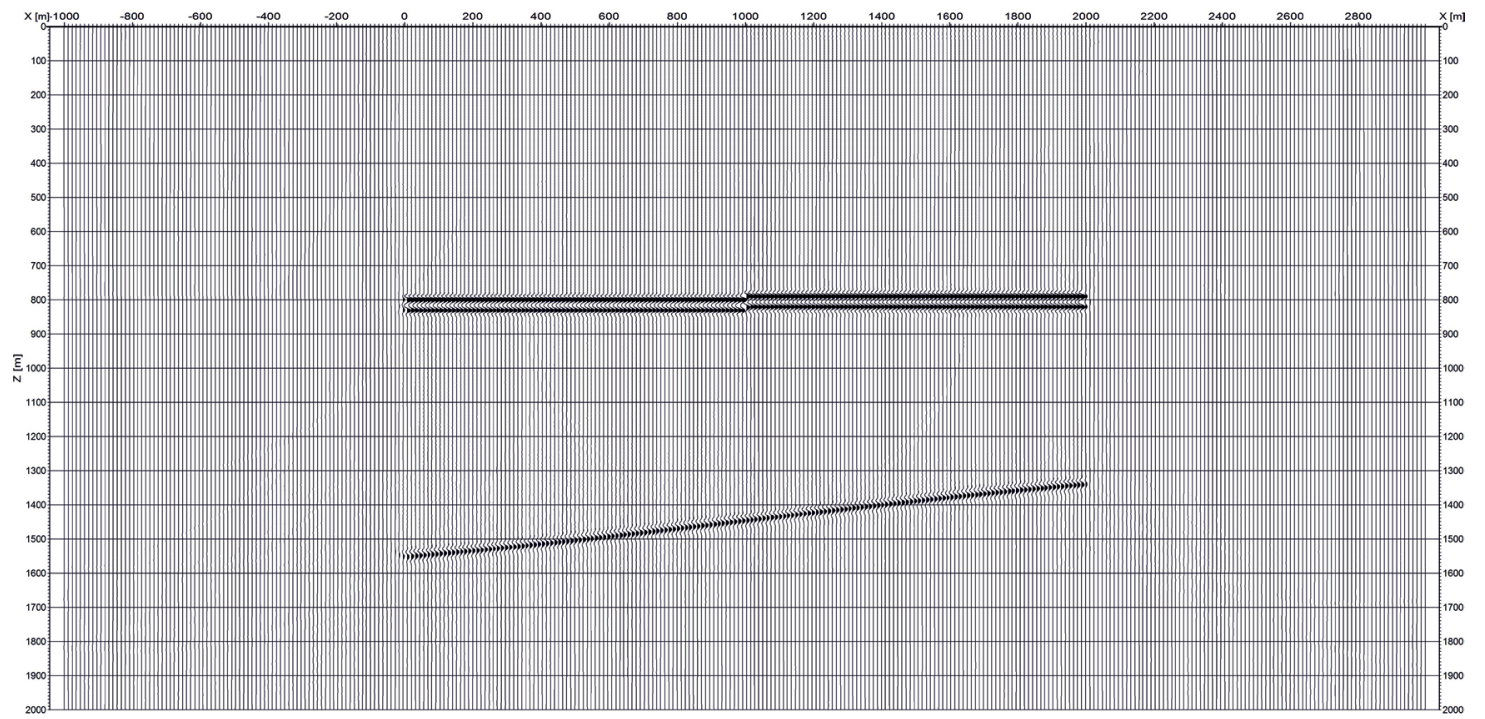

Rys. 7. Migracja zero-offset dla uskoku o zrzucie $10 \mathrm{~m}$ i miąższości warstwy równej $30 \mathrm{~m}$; parametry anizotropii: $\varepsilon=0,4 ; \delta=0,2 ;$ kąt azymutalny $\Psi=45^{\circ}$. Sygnał jednostkowy o częstotliwości dominującej $80 \mathrm{~Hz}$

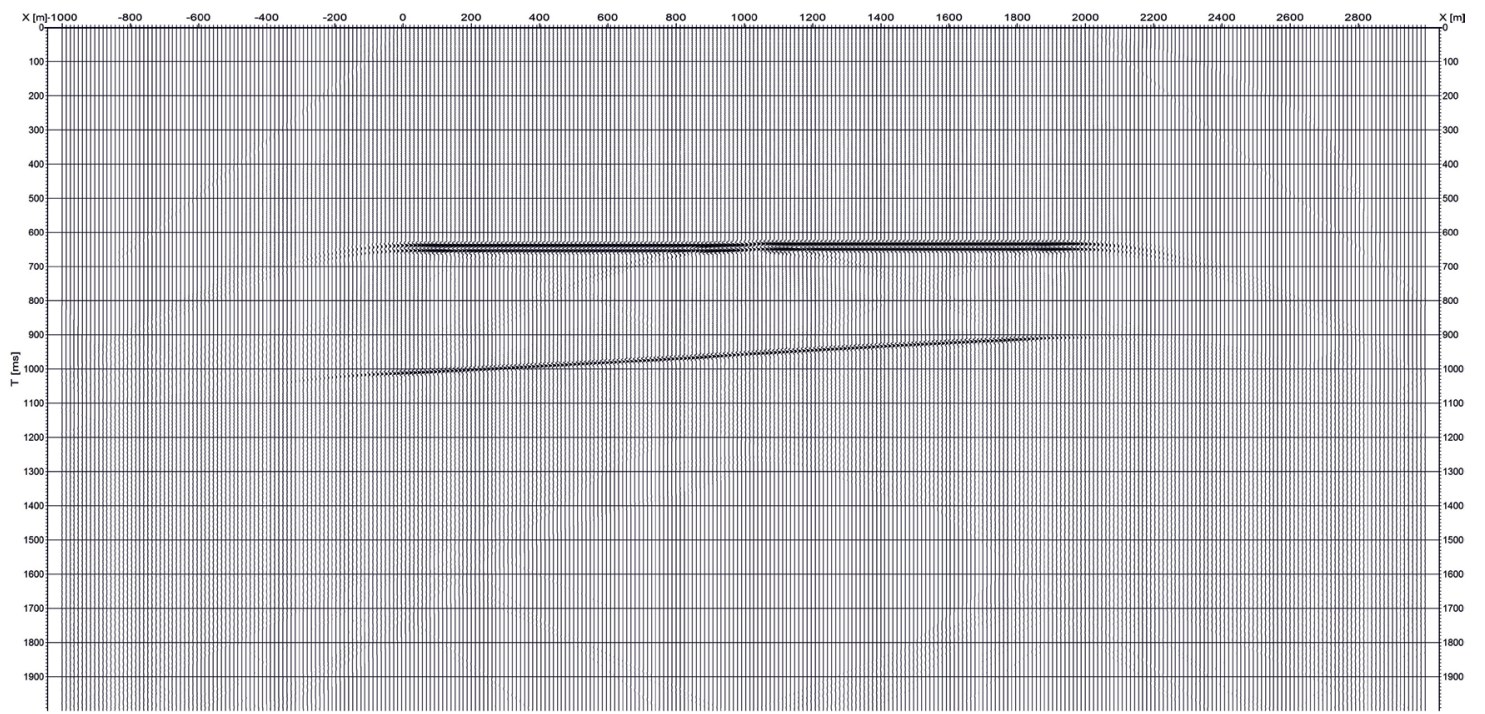

Rys. 8. Sekcja czasowa zero-offset dla uskoku o zrzucie $6 \mathrm{~m}$ i miąższości warstwy równej $30 \mathrm{~m}$; parametry anizotropii: $\varepsilon=0,4 ; \delta=0,2 ;$ kąt azymutalny $\Psi=45^{\circ}$. Sygnał jednostkowy o częstotliwości dominującej $80 \mathrm{~Hz}$

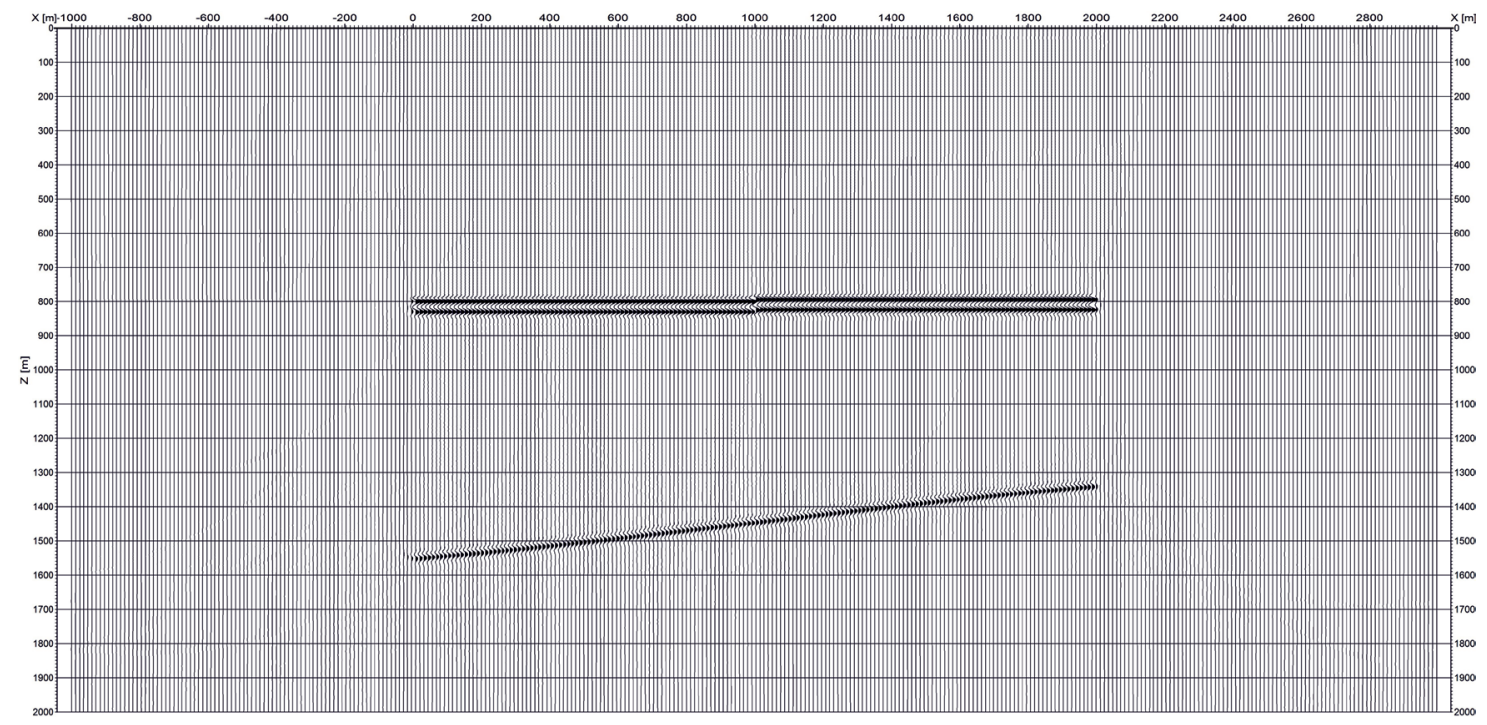

Rys. 9. Migracja zero-offset dla uskoku o zrzucie $6 \mathrm{~m}$ i miąższości warstwy równej $30 \mathrm{~m}$; parametry anizotropii: $\varepsilon=0,4 ; \delta=0,2 ;$ kąt azymutalny $\Psi=45^{\circ}$. Sygnał jednostkowy o częstotliwości dominującej $80 \mathrm{~Hz}$ 


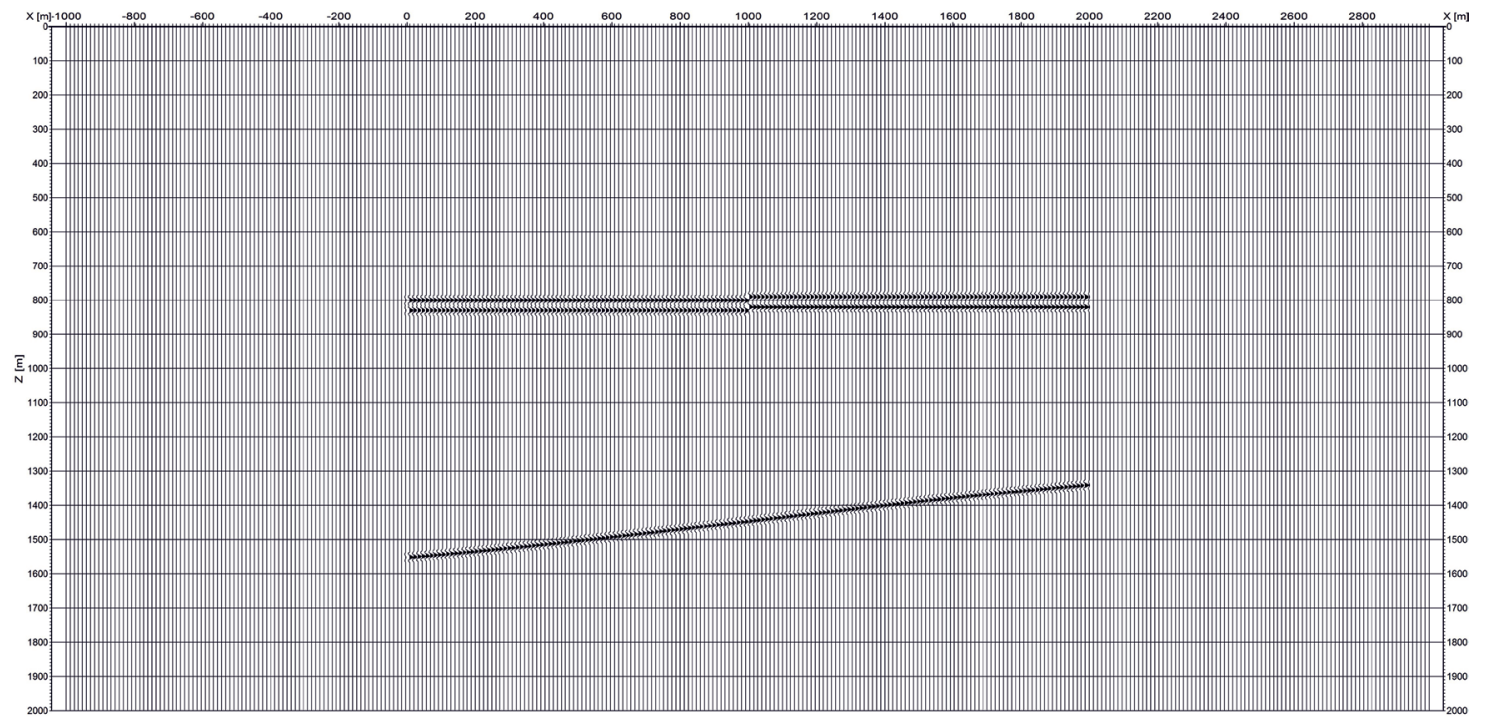

Rys. 10. Geometryczny model uskoku o zrzucie $10 \mathrm{~m}$ i miąższości warstwy równej $30 \mathrm{~m}$

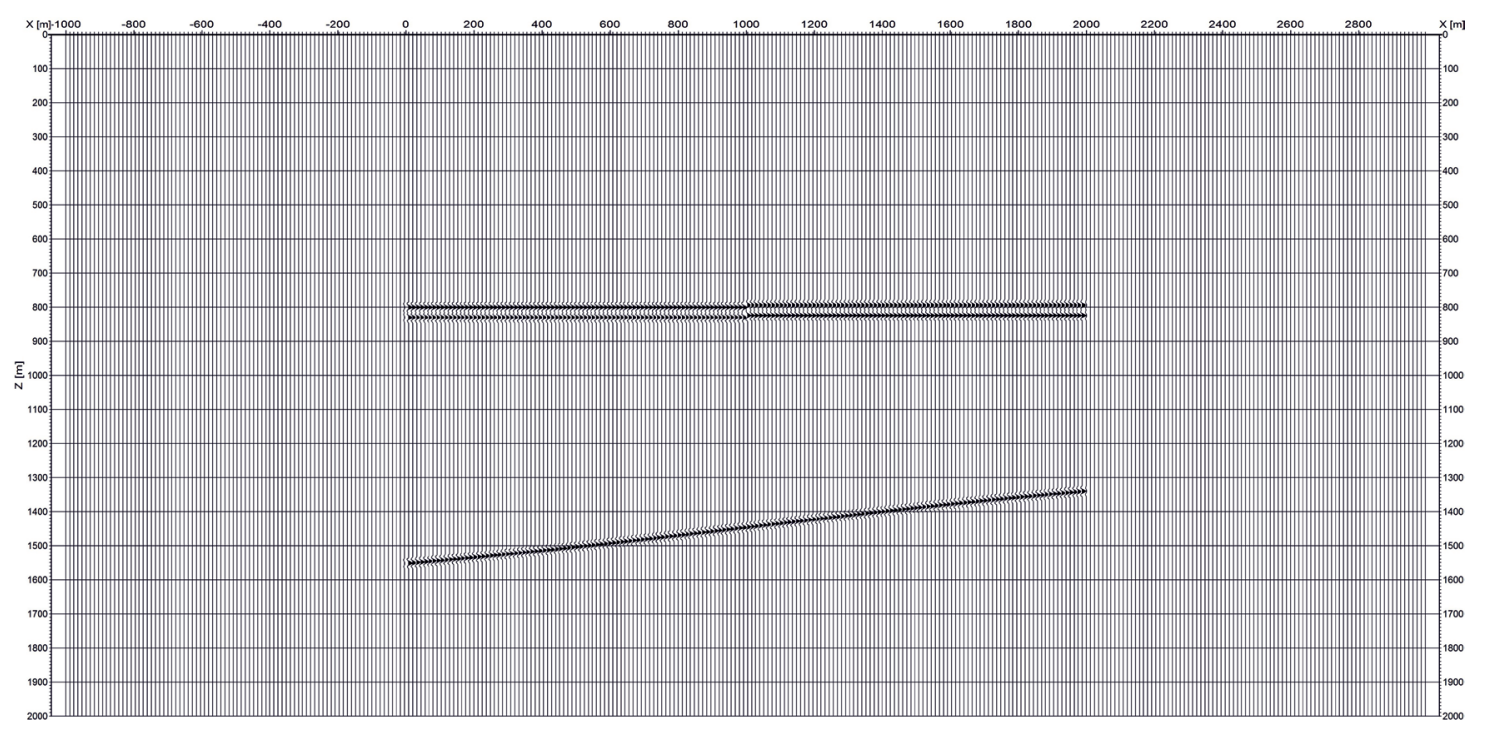

Rys. 11. Geometryczny model uskoku o zrzucie $6 \mathrm{~m}$ i miąższości warstwy równej $30 \mathrm{~m}$

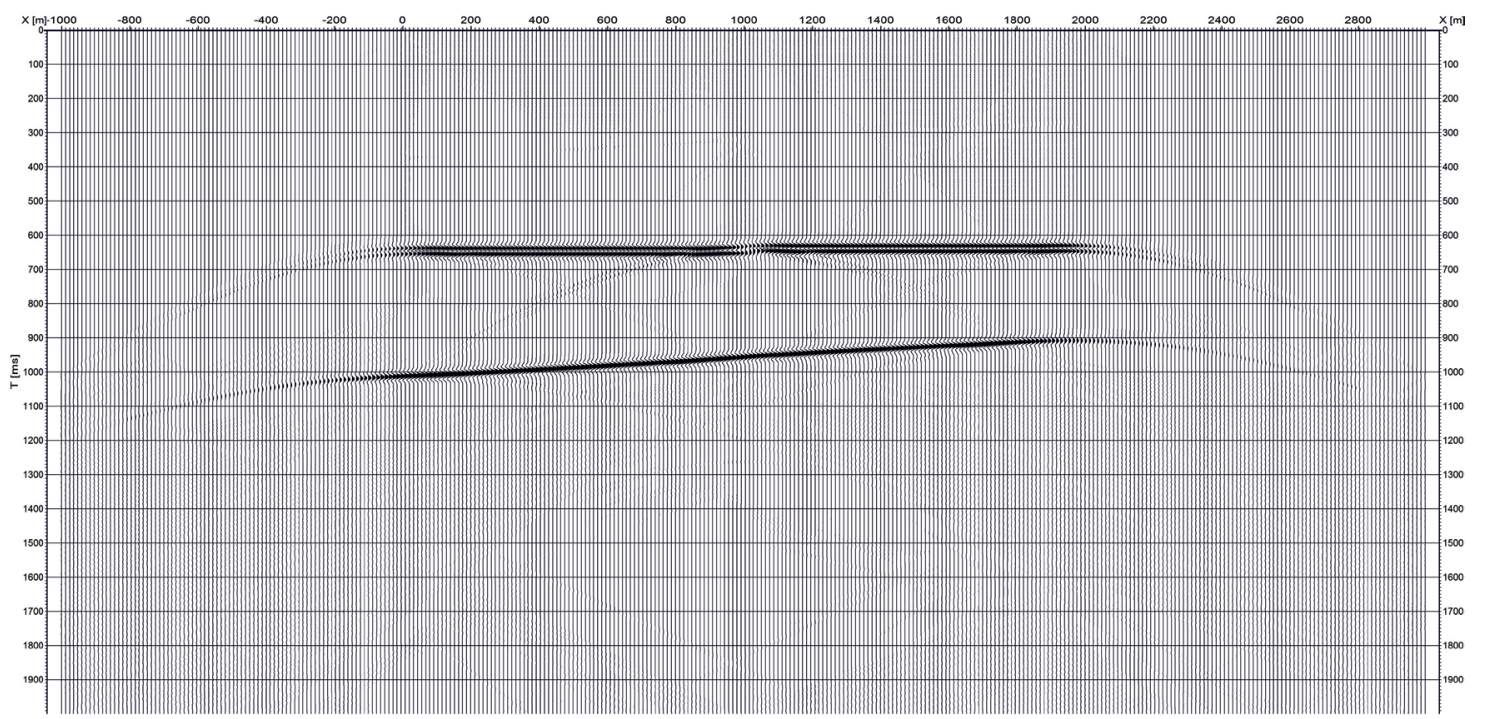

Rys. 12. Sekcja czasowa zero-offset dla uskoku o zrzucie $10 \mathrm{~m}$ i miąższości warstwy równej $30 \mathrm{~m}$; parametry anizotropii: $\varepsilon=0,4 ; \delta=0,2 ;$ kąt azymutalny $\Psi=45^{\circ}$. Sygnał Rickera o częstotliwości dominującej $30 \mathrm{~Hz}$ 


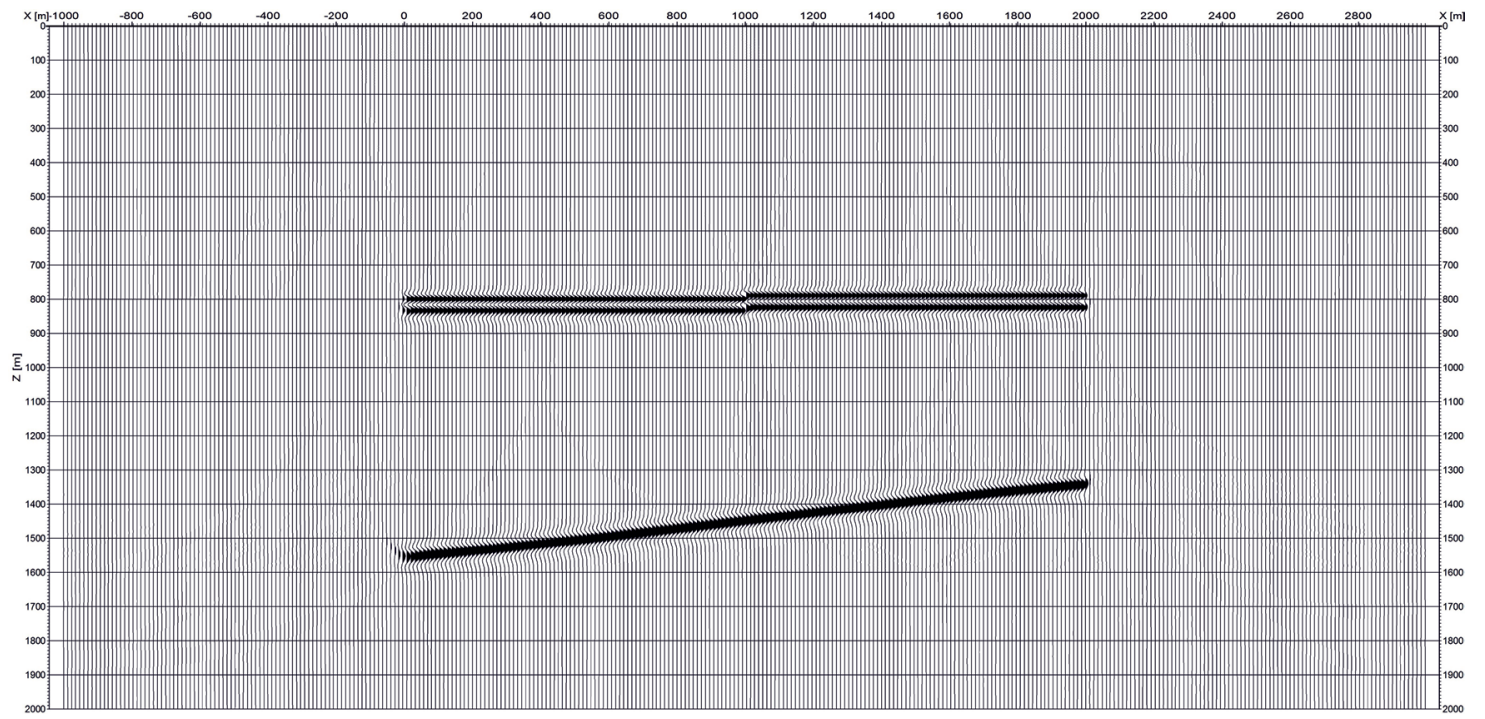

Rys. 13. Migracja zero-offset dla uskoku o zrzucie $10 \mathrm{~m}$ i miąższości warstwy równej $30 \mathrm{~m}$; parametry anizotropii: $\varepsilon=0,4 ; \delta=0,2 ;$ kąt azymutalny $\Psi=45^{\circ}$. Sygnał Rickera o częstotliwości dominującej $30 \mathrm{~Hz}$

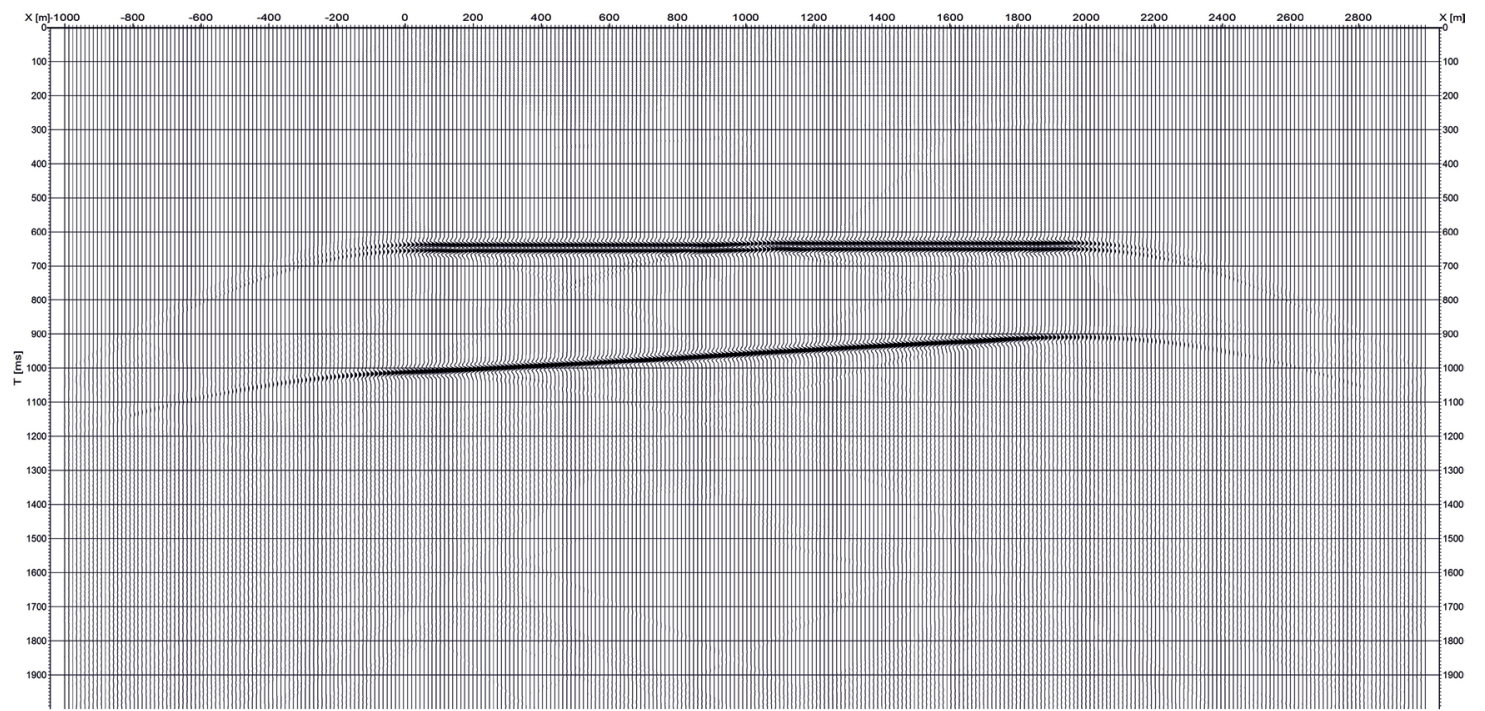

Rys. 14. Sekcja czasowa zero-offset dla uskoku o zrzucie $6 \mathrm{~m}$ i miąższości warstwy równej $30 \mathrm{~m}$; parametry anizotropii: $\varepsilon=0,4 ; \delta=0,2$; kąt azymutalny $\Psi=45^{\circ}$. Sygnał Rickera o częstotliwości dominującej $30 \mathrm{~Hz}$

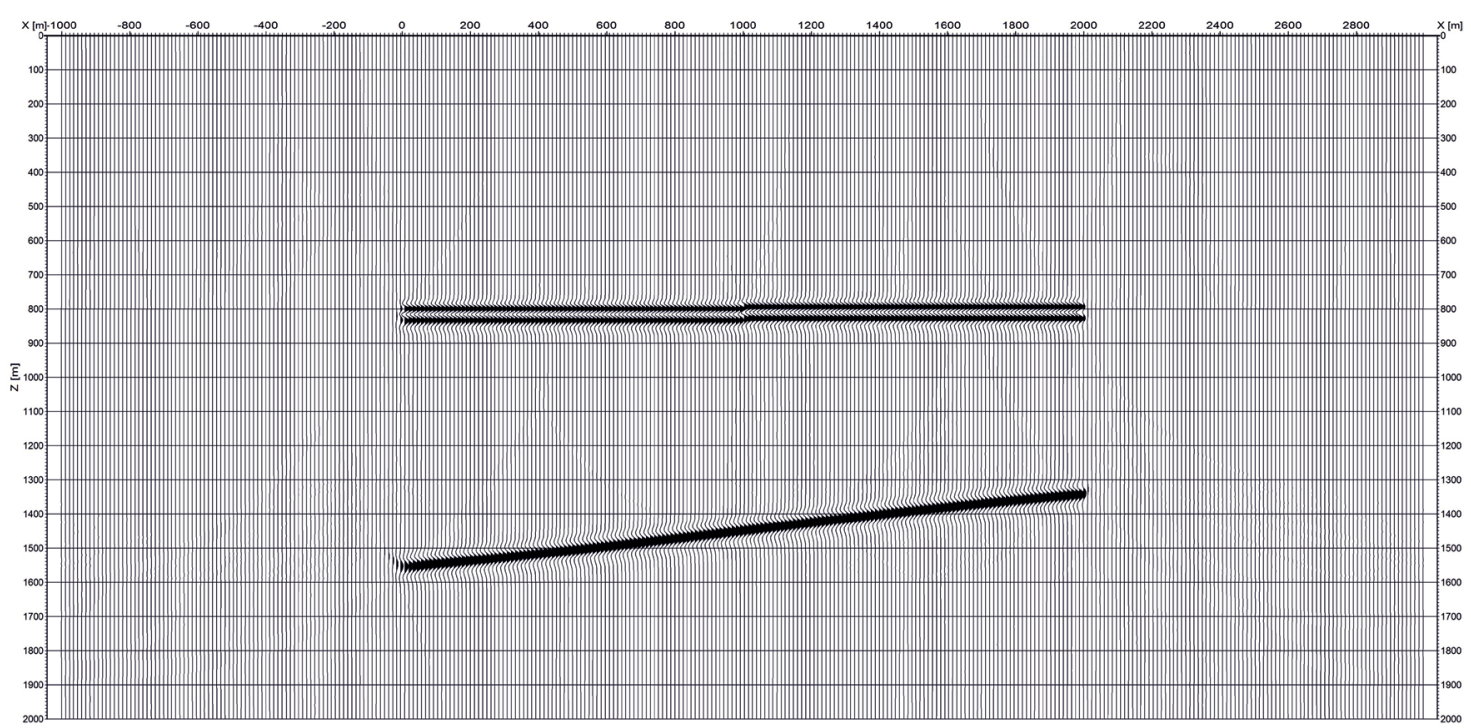

Rys. 15. Migracja zero-offset dla uskoku o zrzucie $6 \mathrm{~m}$ i miąższości warstwy równej $30 \mathrm{~m}$; parametry anizotropii: $\varepsilon=0,4 ; \delta=0,2 ;$ kąt azymutalny $\Psi=45^{\circ}$. Sygnał Rickera o częstotliwości dominującej $30 \mathrm{~Hz}$ 


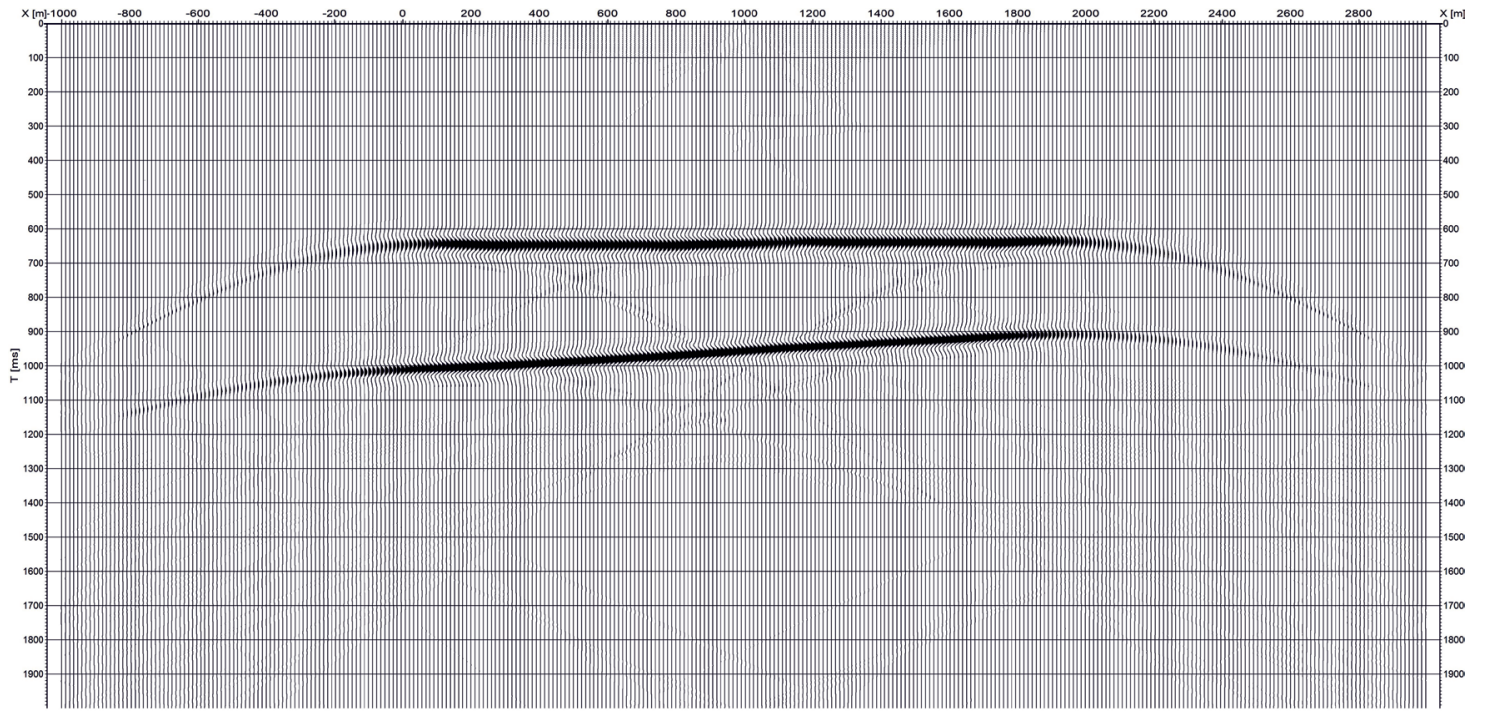

Rys. 16. Sekcja czasowa zero-offset dla uskoku o zrzucie $10 \mathrm{~m}$ i miąższości warstwy równej $30 \mathrm{~m}$; parametry anizotropii: $\varepsilon=0,4 ; \delta=0,2$; kąt azymutalny $\Psi=45^{\circ}$. Sygnał Rickera o częstotliwości dominującej $15 \mathrm{~Hz}$

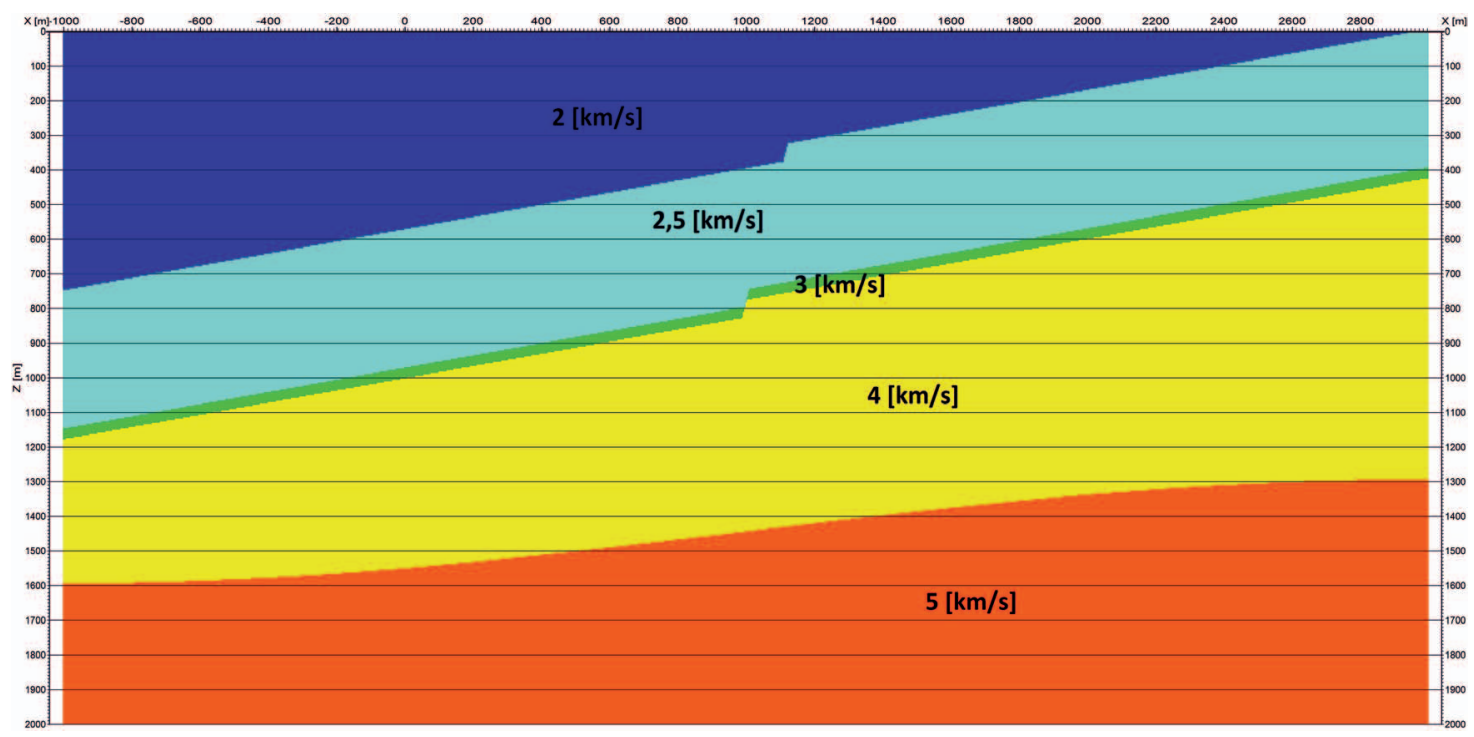

Rys. 17. Model uskoku. Miąższość anizotropowej warstwy HTI o parametrach: $\varepsilon=0,4 ; \delta=0,2 ; \Psi=45^{\circ}$ równa $30 \mathrm{~m}$. Warstwa anizotropowa HTI oznaczona kolorem zielonym

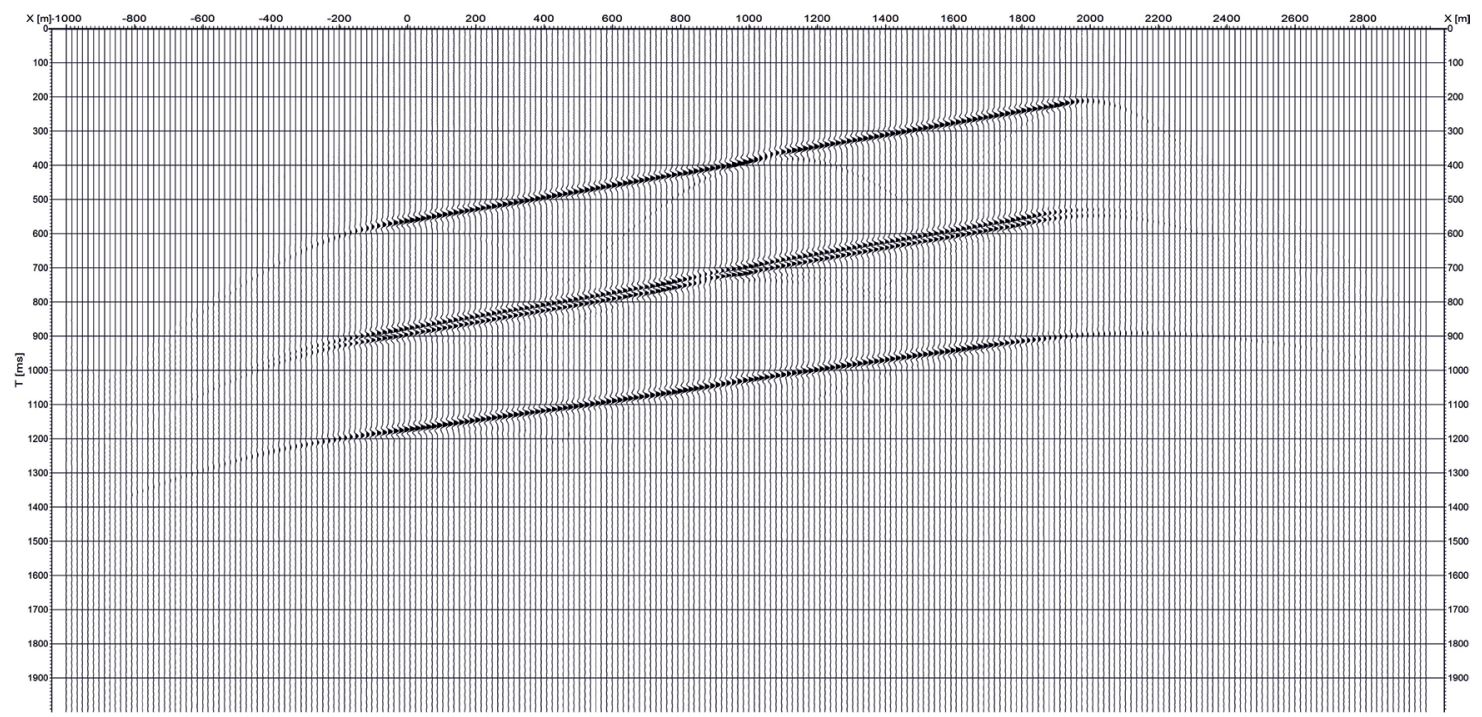

Rys. 18. Sekcja czasowa zero-offset dla uskoku o zrzucie $10 \mathrm{~m}$ i miąższości warstwy równej $30 \mathrm{~m}$; parametry anizotropii: $\varepsilon=0,4 ; \delta=0,2 ;$ kąt azymutalny $\Psi=45^{\circ}$. Sygnał Rickera o częstotliwości dominującej $30 \mathrm{~Hz}$ 


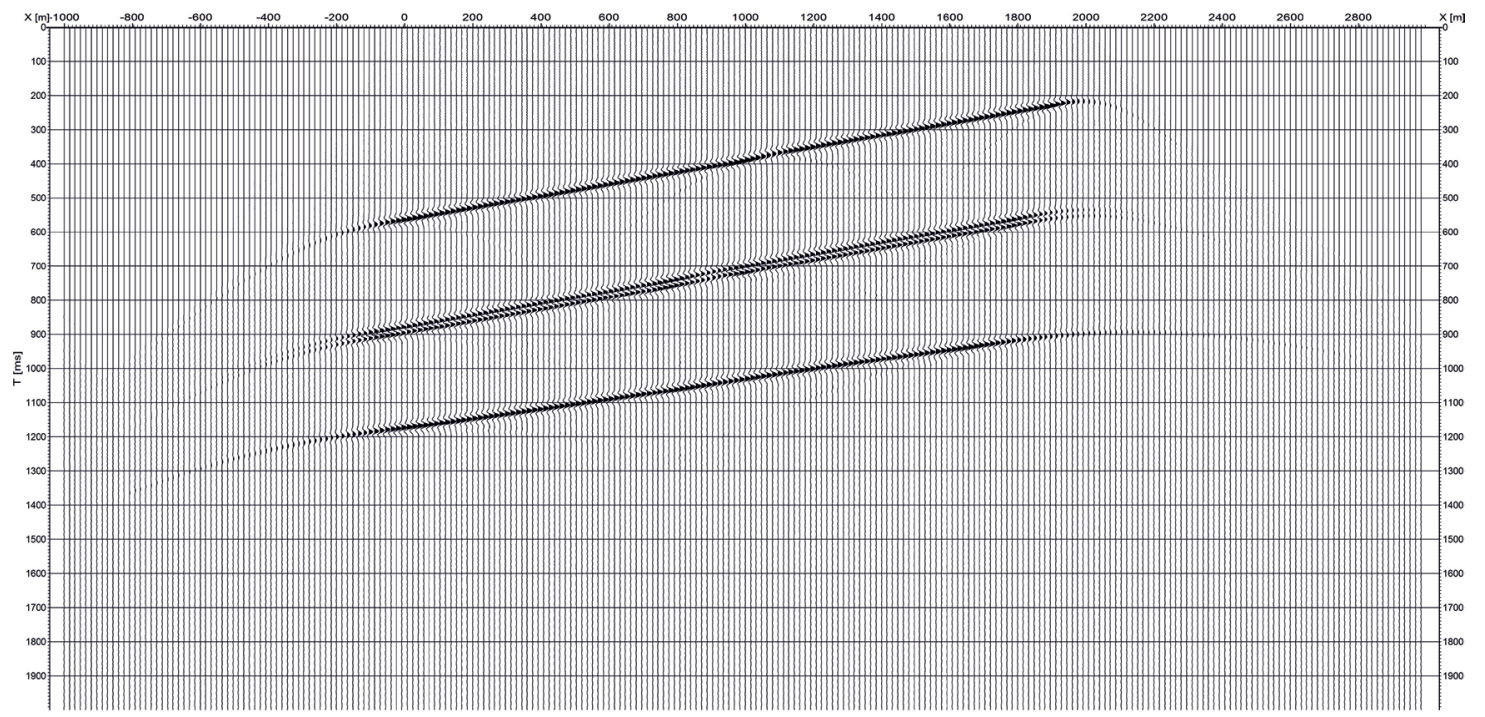

Rys. 19. Sekcja czasowa zero-offset dla uskoku o zrzucie $5 \mathrm{~m}$ i miąższości warstwy równej $30 \mathrm{~m}$; parametry anizotropii: $\varepsilon=0,4 ; \delta=0,2$; kąt azymutalny $\Psi=45^{\circ}$. Sygnał Rickera o częstotliwości dominującej $30 \mathrm{~Hz}$

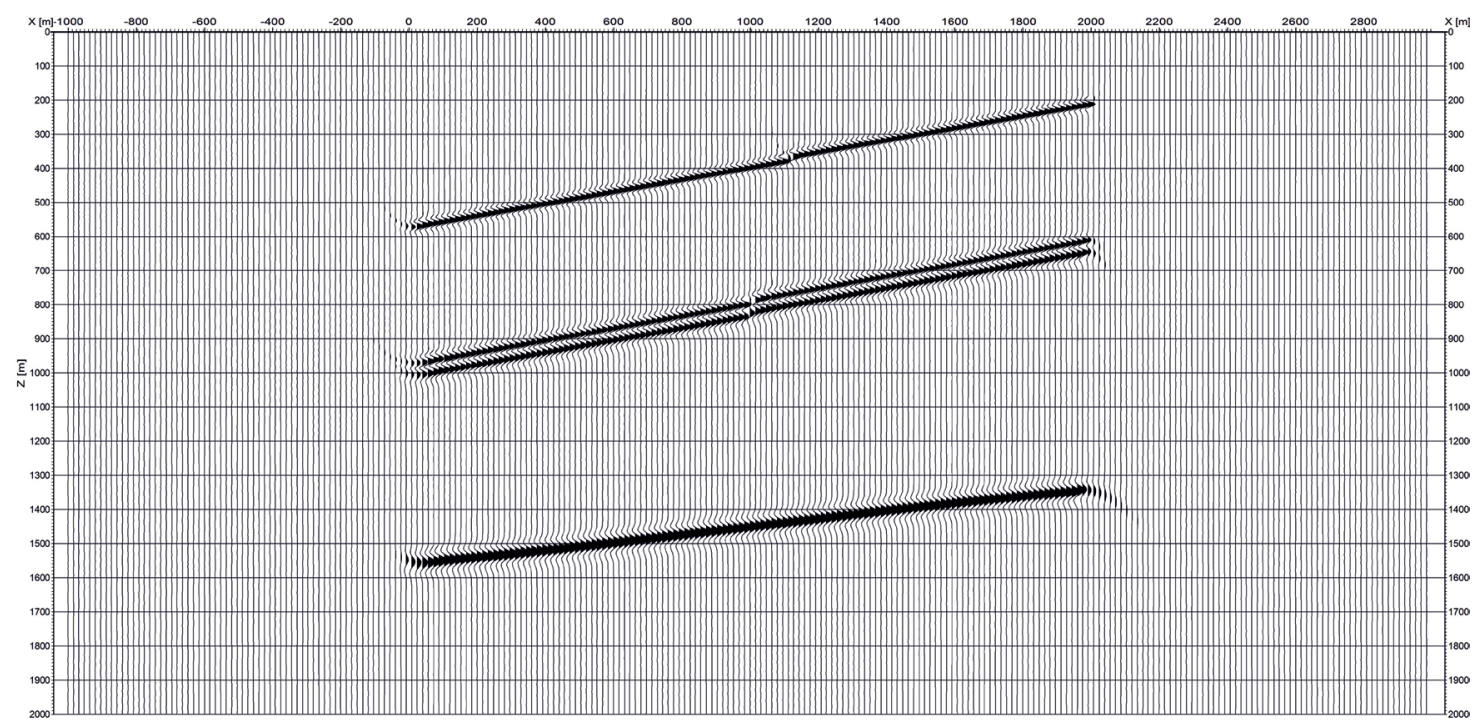

Rys. 20. Migracja zero-offset dla modelu z warstwą anizotropową HTI o miąższości $30 \mathrm{~m}$ i zrzucie $10 \mathrm{~m}$; parametry anizotropii: $\varepsilon=0,4 ; \delta=0,2$; kąt azymutalny $\Psi=45^{\circ}$. Pole falowe - rys. 18

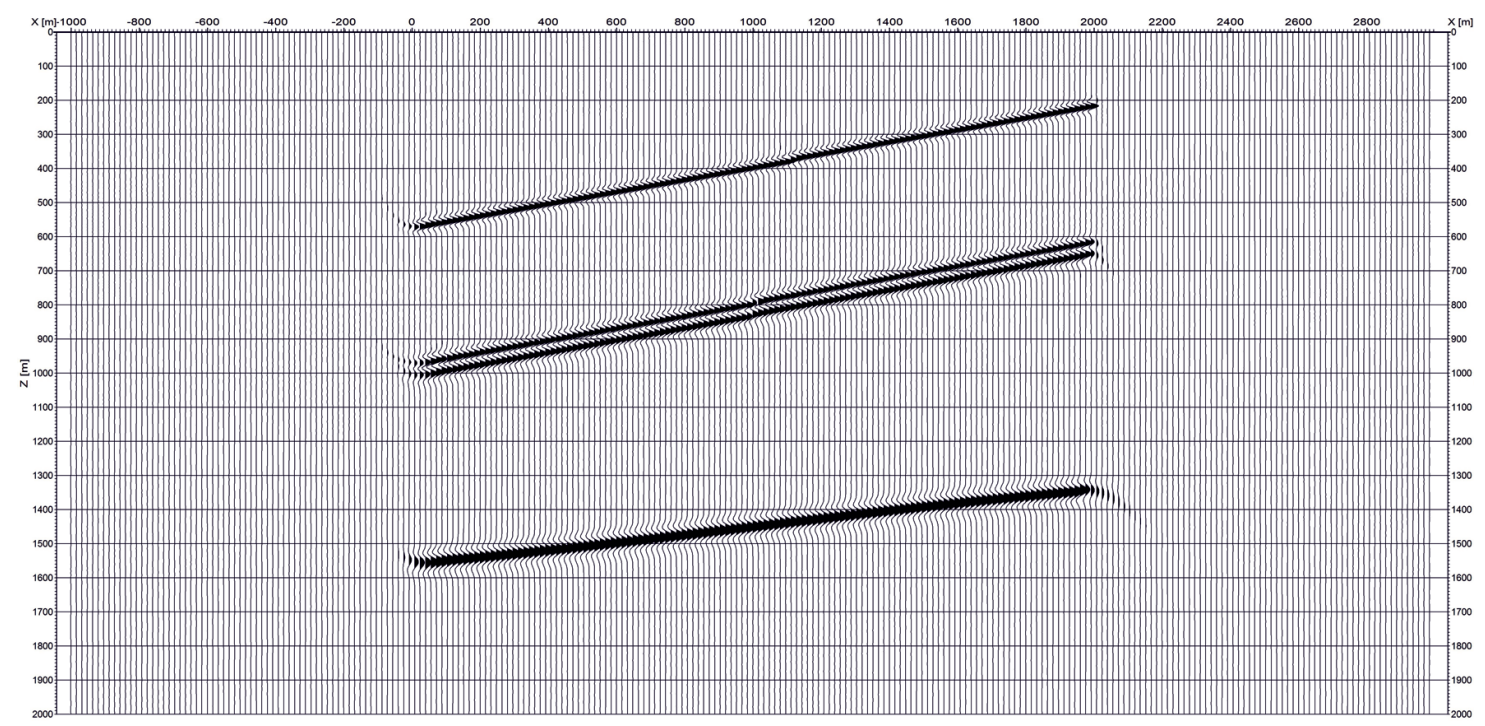

Rys. 21. Migracja zero-offset dla modelu z warstwą anizotropową HTI o miąższości $30 \mathrm{~m}$ i zrzucie $5 \mathrm{~m}$; parametry anizotropii: $\varepsilon=0,4 ; \delta=0,2$; kąt azymutalny $\Psi=45^{\circ}$. Pole falowe - rys. 19 
Kolejny cykl eksperymentów w strefie uskokowej obejmował modelowanie i migrację na modelu nachylonej warstwy izotropowej o prędkości $2500 \mathrm{~m} / \mathrm{s}$, w której spągu występuje warstwa anizotropowa HTI o prędkości bazowej $V_{P}=3000 \mathrm{~m} / \mathrm{s}$, parametrach Thomsena: $\varepsilon=0,4$; $\delta=0,2$ i kącie azymutalnym $\Psi=45^{\circ}$ (rysunek 17). Na rysunkach 18 i 19 zaprezentowano sekcję czasową o zrzutach $10 \mathrm{~m}$ i $5 \mathrm{~m}$ warstwy o miąższości $30 \mathrm{~m}$ z użyciem sy- gnału Rickera $30 \mathrm{~Hz}$. W przypadku zrzutu $10 \mathrm{~m}$ obserwuje się zmniejszanie amplitud zasadniczego uskoku warstwy HTI i wyżej leżącego uskoku warstwy izotropowej, natomiast w przypadku uskoku o zrzucie $5 \mathrm{~m}$ (rysunek 19) zauważa się nieznaczne osłabienie dla uskoku HTI. Odwzorowania migracyjne (rysunki 20 i 21) ujawniają wyraźnie istnienie uskoku dla zrzutu $10 \mathrm{~m}$ i oznaki nieciągłości dla uskoku o zrzucie $5 \mathrm{~m}$.

\section{Konkluzje}

Rezultaty eksperymentów modelowań i migracji pozwalają sformułować następujące wnioski:

1. Pole falowe zero-offset pionowych uskoków w ośrodku anizotropowym HTI jest niezależne od kąta azymutalnego $\Psi$. Zjawisko to stanowi wynik kształtowania pola falowego głównie przez pionową i zbliżoną do pionowej propagację fal. Fale o horyzontalnym kierunku propagacji zależne od kąta azymutalnego $\Psi$ praktycznie nie biorą udziału w konstrukcji sumarycznego pola zero-offset dla pionowego uskoku. Również w przypadku umiarkowanych kątów upadu warstw tworzących uskok dominujący wpływ na ukształtowanie pola falowego ma pionowy przebieg fal. We wspomnianych przypadkach warstwy o anizotropii HTI zachowują się jak izotropowe o pręd- kości równej $V_{P}(1+2 \varepsilon)^{1 / 2}$, gdzie $V_{p}$ jest prędkością bazową fal podłużnych, a $\varepsilon$ parametrem Thomsena.

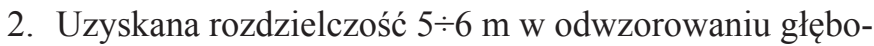
kościowym przy użyciu sygnału o częstotliwości dominującej $80 \mathrm{~Hz}$ i sygnału Rickera $30 \mathrm{~Hz}$ pozycjonuje ten rezultat w zakresie kryterium rozdzielczości określonym przez Widessa [9].

3. Posługiwanie się sygnałem Rickera o dominującej częstotliwości $15 \mathrm{~Hz}$ skutkuje wyraźnym zmniejszeniem rozdzielczości, dla zrzutu $10 \mathrm{~m}$ uskok jest niezauważalny.

4. Odwzorowanie stref uskokowych w ośrodku anizotropowym HTI metodą migracji MG(F-K) zero-offset jest zbieżne z założonymi modelami geometrycznymi.

Prosimy cytować jako: Nafta-Gaz 2017, nr 12, s. 918-927, DOI: 10.18668/NG.2017.12.02

Artykuł nadesłano do Redakcji 29.06.2016 r. Zatwierdzono do druku 6.09.2017 r.

Artykuł powstał na podstawie badań zrealizowanych w ramach projektu pt.: Badania sejsmiczne i ich zastosowanie dla detekcji stref występowania gazu z lupków. Dobór optymalnych parametrów akwizycji i przetwarzania w celu odwzorowania budowy strukturalnej oraz rozkładu parametrów petrofizycznych i geomechanicznych skat perspektywicznych, dofinansowanego przez Narodowe Centrum Badań i Rozwoju w ramach programu BLUE GAS - POLSKI GAZ ŁUPKOWY. Nr umowy: BG1/GASLUPSEJSM/13.

\section{Literatura}

[1] Gazdag I.: Modeling of the acoustic wave equation with transform methods. Geophysics 1981, vol. 46, nr 6, s. 854-859.

[2] Kostecki A., Półchłopek A.: Stable depth extrapolation of seismic wavefields by a Neumann series. Geophysics 1998, vol. 63, nr 6, s. $2063-2071$.

[3] Kostecki A., Żuławiński K.: Forward and back-propagation of compressional waves in horizontal transverse isotropy (HTI) media. Prace Naukowe Instytutu Nafty i Gazu - Państwowego Instytutu Badawczego 2016, nr 212, DOI: 10.18668/PN2016.212.

[4] Kostecki A., Żuławiński K.: Modeling and seismic migration in anisotropic media as a function of azimuthal angle HTI ( $\Psi)$. Nafta-Gaz 2016, nr 9, s. 679-690, DOI: 10.18668/NG.2016.09.01.

[5] Kostecki A., Żuławiński K.: Modelowanie i migracja sekcji cza-

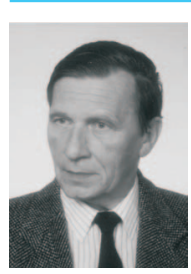

Prof. dr hab. inż. Andrzej KOSTECKI

Profesor zwyczajny

Instytut Nafty i Gazu - Państwowy Instytut Badawczy ul. Lubicz 25 A

31-503 Kraków

E-mail: andrzej.kostecki@inig.pl sowych zero-offsetowych $w$ ośrodkach TTI metoda pseudospektralna. Nafta-Gaz 2014, nr 12, s. 855-860.

[6] Kostecki A., Żuławiński K.: Propagacja fal podtużnych w ośrodkach anizotropowych na przyktadzie struktury uskokowej horstu. X Międzynarodowa Konferencja Naukowo-Techniczna Geopetrol 2016, Prace Naukowe Instytutu Nafty i Gazu - Państwowego Instytutu Badawczego 2016, nr 209, s. 211-221.

[7] Loewenthal D., Lu L., Robertson R., Sherwod I.: The wave equation applied to migration. Geophysical Prospecting 1976, vol. 24, nr 2, s. 380-399.

[8] Thomsen L.: Weak elastic anisotropy. Geophysics 1986, vol. 51, no. 10, s. 1954-1966.

[9] Widess M.: How thin is a thin bed? Geophysics 1973, vol. 38, nr 6, s. 1176-1180.

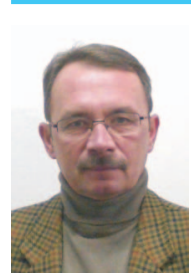

Mgr inż. Krzysztof ŻUŁAWIŃSKI

Starszy specjalista badawczo-techniczny; p.o. kierownika Zakładu Sejsmiki. Instytut Nafty i Gazu - Państwowy Instytut Badawczy ul. Lubicz 25 A

31-503 Kraków

E-mail:krzysztof.zulawinski@inig.pl 